\title{
FACTORS DETERMINING THE PSYCHOMETRIC ASSESSMENT OF PATIENTS AFTER HIP REPLACEMENT SURGERY
}

\section{CZYNNIKI WARUNKUJĄCE OCENĘ PSYCHOMETRYCZNĄ PACJENTÓW PO PROTEZOPLASTYCE STAWU BIODROWEGO}

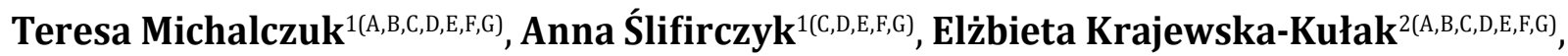 \\ Paweł Piszcz $^{1(C, D, E, F)}$, Agnieszka Gałecka ${ }^{3(C, D, E, F)}$, Marta Kowalenko ${ }^{1(C, D, E, F)}$
}

\author{
${ }^{1}$ Department of Medical Rescue, Pope John Paul II State School of Higher Education in Biała Podlaska, Poland \\ ${ }^{2}$ Department of Integrated Medical Care, Medical University of Bialystok, Poland \\ ${ }^{3}$ Department of Finance and Accounting, Pope John Paul II State School of Higher Education in Biała Podlaska, Poland
}

Authors' contribution

Wkład autorów:

A. Study design/planning

zaplanowanie badań

B. Data collection/entry

zebranie danych

C. Data analysis/statistics dane - analiza i statystyki D. Data interpretation interpretacja danych E. Preparation of manuscript przygotowanie artykułu F. Literature analysis/search wyszukiwanie i analiza literatury G. Funds collection zebranie funduszy

\section{Summary}

Background. The aim of this study was to investigate the influence of selected factors such as place of residence, education, age, duration of hospitalization and pain intensity before and after hip replacement surgery on the level of acceptance of the illness, on the subjective assessment of the patient's state of health during surgery and on the level of pain and the ability to manage and reduce pain. Material and methods. The study included 181 patients diagnosed with hip joint degeneration and qualified for total hip replacement hospitalized in the Regional Specialist Hospital in Biała Podlaska, Poland. The study was conducted by means of a diagnostic survey with the use of a set of questionnaires: Acceptance of Illness Scale AIS, WOMAC Scale, SF-36 Questionnaire, BPCQ Questionnaire. Results. More than half of the respondents (55.2\%) were highly accepting of their condition. The level of acceptance was influenced by the place of residence, education, age, the intensity of pain after surgery and functional limitation. The overall assessment of the quality of life in the physical domain was -62.9 points, with the worst scores for physical functioning and general health. Analysis with the WOMAC questionnaire showed that the majority of the subjects scored below 50 points on the functional limitation scale. All factors, except the level of pain before surgery, influenced the degree of functional limitation. Conclusions. Age, place of residence and education provided opportunities for pain control and the ability to reduce pain was perceived by those with longer hospital stays. Participants from cities had the highest quality of life. Education influenced the quality of life, which decreased with age and higher pain intensity. The better the quality of life, the higher the level of acceptance of illness, and vice versa.

Keywords: arthroplasty, quality of life, pain, hospitalization

\section{Streszczenie}

Wprowadzenie. Celem niniejszej pracy było zbadanie wpływu wybranych czynników takich jak: miejsce zamieszkania, wykształcenie, wiek, czas hospitalizacji oraz nasilenie bólu przed i po zabiegu operacyjnym protezoplastyki biodra na poziom akceptacji choroby, na subiektywną ocenę stanu zdrowia operowanego pacjenta oraz na poziom bólowy i umiejętność panowania nad bólem i jego obniżeniem. Materiał i metody. Badaniem objętych zostało 181 pacjentów z rozpoznaniem zwyrodnienia stawu biodrowego i zakwalifikowanych do zabiegu operacyjnego całkowitej alloplastyki biodra hospitalizowanych w Wojewódzkim Szpitalu Specjalistycznym w Białej Podlaskiej. Badanie przeprowadzono metodą sondażu diagnostycznego z wykorzystaniem zestawu kwestionariuszy: Skali Akceptacji Choroby - AIS, Skali WOMAC, Kwestionariusza SF-36, Kwestionariusza BPCQ. Wyniki. Stwierdzono, że ponad połowa badanych $(55,2 \%)$ w wysokim stopniu akceptowała swoje schorzenie. Na poziom akceptacji miały wpływ: miejsce zamieszkania, wykształcenie, wiek, natężenie bólu po zabiegu oraz ograniczenie sprawności funkcjonalnej. Ogólna ocena jakości życia w dziedzinie fizycznej wynosiła - 62,9 pkt., przy czym najgorzej wypadła ocena funkcjonowania fizycznego oraz zdrowia ogólnego. Analiza za pomocą kwestionariusza WOMAC wykazała, że większość badanych, w pomiarze stopnia ograniczenia sprawności funkcjonalnej, uzyskała poniżej 50 pkt. Wszystkie czynniki, poza poziomem bólu przed zabiegiem, wpływały na stopień ograniczenia sprawności. Wnioski. Wiek, miejsce zamieszkania oraz wykształcenie dały możliwości panowania nad bólem, a o możliwości jego zmniejszenia wiedziały osoby dłużej hospitalizowane. Najwyższa jakościa życia charakteryzowały się osoby z dużych miast. Wykształcenie wpłynęło na jakość życia, która wraz z wiekiem i wyższym natężeniem bólu spadała. Im lepsza jakość życia, tym wyższy poziom akceptacji choroby i odwrotnie.

Słowa kluczowe: protezoplastyka, jakość życia, ból, hospitalizacja
Tables: 14

Figures: 10

References: 31

Submitted: 2020 Nov 17

Accepted: 2021 Apr 7

hip replacement surgery. Health Prob Civil. 2021; 15(2): 87-100. https://doi.org/10.5114/hpc.2021.105419

Address for correspondence / Adres korespondencyjny: Anna Ślifirczyk, Department of Medical Rescue, Pope John Paul II State School of Higher Education, Sidorska 95/97, 21-500 Biała Podlaska, Poland, e-mail: aslifirczyk1@gmail.com, phone: +48 833449900

ORCID: Anna Ślifirczyk https://orcid.org/0000-0002-2495-025X, Elżbieta Krajewska-Kułak https://orcid.org/0000-0002-9425-2430,

Agnieszka Gałecka https://orcid.org/0000-0002-7603-8086, Marta Kowalenko https://orcid.org/0000-0001-7785-2947

Copyright: (c) Pope John Paul II State School of Higher Education in Biała Podlaska, Teresa Michalczuk, Anna Ślifirczyk, Elżbieta Krajewska-Kułak, Paweł Piszcz, Agnieszka Gałecka, Marta Kowalenko. This is an Open Access journal, all articles are distributed under the terms of the Creative Commons Attribution-NonCommercial-ShareAlike 4.0 International (CC BY-NC-SA 4.0) License (http://creativecommons.org/licenses/by-nc-sa/4.0/), allowing third parties to copy and redistribute the material in any medium or format and to remix, transform, and build upon the material, provided the original work is properly cited and states its license. 


\section{Introduction}

Osteoarthritis of the hip (coxarthrosis) is now recognized as one of the main causes leading to severe locomotor dysfunction, including pain and significant limitation in range of motion. Degenerative processes in the articular cartilage of the hip start as early as the second decade of life [1]. Research shows that one in four older people will develop full-blown osteoarthritis of the hip and one in ten patients will opt for a total hip replacement [2,3].

Despite widespread familiarity with the term "osteoarthritis", there is no fully accepted definition of this condition [4]. The disease is thought to result from a combination of mechanical and biological factors destabilizing the interrelated processes of degradation and synthesis of articular cartilage and the subchondral layer of bone and affects all tissues of the joint. It manifests as morphological, biochemical, molecular and biomechanical alterations of cells and extracellular matrix that lead to softening, fibrocartilage, ulceration and loss of articular cartilage, hardening and thickening of the subchondral bone tissue and formation of osteophytes and subchondral cysts [4].

The clinical presentation of osteoarthritis is characterized by joint pain, pressure soreness, restricted mobility, crackling and sometimes exudation. Over the course of time, joint cartilage loses its elasticity, which makes it more difficult to absorb shocks and bumps, and leads to more rapid damage. Cartilage defects are filled in by scar tissue. With repeated injuries, exudative and inflammatory reactions, prolonged excessive pressure and immobility, it degrades. It becomes dull, cracked and abraded. On the subchondral side of the bone layer, vessels grow into the cartilage, around which a process of ossification and calcification occurs. Bone growths called osteophytes are formed. The head of the femur bone begins to fracture under pressure. The underlying bone under the cartilage becomes exposed and damaged. As a result of ischaemia, the bone tissue dies and the joint is destroyed. Injuries lead to fractures in the hip joint and the bones do not grow together properly [5].

Until recently, fixation was considered the best method of treatment for osteoarthritis of the hip joint, but advances in medicine have led to the introduction of endoprosthesis (alloplasty), which involves the partial or total replacement of the damaged joint [6-8]. This method is considered to be the most important method of surgical treatment of osteoarthritis of the hip joint, giving patients a chance to alleviate pain, restore a wide range of motion in the hip joints, and improve gait performance $[7,8]$.

It is worth noting that the number of implanted endoprostheses is increasing every year. Annually, more than 1.3 million endoprostheses are performed worldwide [9] and it is estimated, according to Mamlin et al., that, e.g. in the USA, this number will increase by nearly 85\% by 2030 [10]. Data from the National Health Fund's Central Endoprosthesis Database show that in 2016, approximately 134\% more joint endoprosthesis services were performed compared to 2005 [11].

It is noted [12-14] that the length of time and programme for the rehabilitation of patients after hip replacement varies slightly between different treatment and rehabilitation centers, but always has the same aim - early upright mobilization, speedy return of static and dynamic functions, shortening the length of stay of patients in hospital wards and improving the quality of life of patients.

\section{Material and methods}

The study was carried out after obtaining the consent from the Bioethics Committee R-I-002/246/2018 of the Medical University of Bialystok and the Directorate of the Regional Specialist Hospital in Biała Podlaska, 57-65 Terebelska Street, Poland, HDS.KM.0718/21-4941/18. The study included 181 patients diagnosed with osteoarthritis of the hip joint and qualified for total hip arthroplasty surgery and hospitalized in the Regional Specialist Hospital in Biała Podlaska between 2010 and 2017.

Using a set of questionnaires, a diagnostic survey was conducted to demonstrate patients' quality of life (AIS - Acceptance of Illness Scale), assessing pain, progression of osteoarthritis, and effectiveness of causal and symptomatic treatment, in patients with knee or hip osteoarthritis (WOMAC - The Western Ontario and McMaster Universities Osteoarthritis Index), subjectively assessing the health status of patients undergoing hip replacement (SF-36 Questionnaire), examining individual beliefs about pain control by a physician, internally or by chance events (BPCQ - Beliefs about Pain Control Questionnaire) and by examining coping strategies (CSQ The Pain Coping Strategies Questionnaire).

\section{Results}

In the first part, the influence of selected factors on the level of acceptance of the disease was examined. The following factors were considered: place of residence, education and age, duration of hospitalization and pain 
intensity before and after surgery. The place of residence quite clearly differentiated the level of acceptance of the disease - there was a particularly large difference between patients from large cities and the remaining individuals (Table 1, Figure 1).

Table 1. AIS score in relation to place of residence

\begin{tabular}{|c|c|c|c|c|c|c|c|}
\hline \multirow{2}{*}{ Acceptance of Illness Score } & \multicolumn{9}{|c|}{ Place of Residence } & \multirow{2}{*}{ City } \\
\cline { 2 - 8 } & \multicolumn{2}{|c|}{ Village } & \multicolumn{2}{c|}{ Town } & \multicolumn{3}{c|}{ P } \\
\cline { 2 - 8 } & $\overline{\boldsymbol{x}}$ & $\boldsymbol{s}$ & $\overline{\boldsymbol{x}}$ & $\boldsymbol{s}$ & $\overline{\boldsymbol{x}}$ & 7.5 & $0.0051^{* *}$ \\
\hline \multirow{2}{*}{ AIS (pts.) } & 27.6 & 7.4 & 29.1 & 6.7 & 32.7 & 7.7 \\
\hline
\end{tabular}

Notes: $p$ - test probability value calculated using the Kruskal-Wallis test.

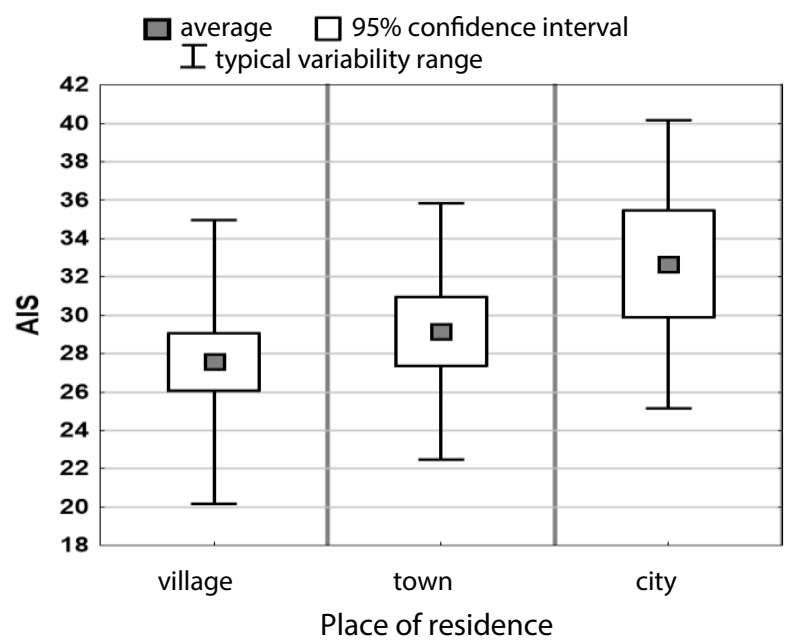

Figure 1. AIS score in relation to place of residence

Education was also a factor that significantly differentiated the level of acceptance of the illness (test probability value $\mathrm{p}=0.0000^{* * *}$ ). Individuals with a higher level of education showed a much higher level of acceptance of the illness - the difference in mean values between the extreme groups was more than 10 points (Table 2).

Table 2. AIS score in relation to education

\begin{tabular}{|c|c|c|c|c|c|c|c|c|c|}
\hline \multirow{3}{*}{$\begin{array}{l}\text { Acceptance of } \\
\text { Illness Score }\end{array}$} & \multicolumn{8}{|c|}{ Education } & \multirow{3}{*}{$\mathbf{p}$} \\
\hline & \multicolumn{2}{|c|}{ Primary } & \multicolumn{2}{|c|}{ Vocational } & \multicolumn{2}{|c|}{ Secondary } & \multicolumn{2}{|c|}{ Higher } & \\
\hline & $\overline{\boldsymbol{x}}$ & $s$ & $\overline{\boldsymbol{x}}$ & $s$ & $\overline{\boldsymbol{x}}$ & $s$ & $\overline{\bar{x}}$ & $s$ & \\
\hline AIS (pts.) & 24.8 & 7.7 & 27.3 & 6.3 & 31.0 & 6.6 & 35.6 & 6.8 & $0.0000^{* * *}$ \\
\hline
\end{tabular}

Notes: $p$ - test probability value calculated using the Kruskal-Wallis test.

Also, the percentage distribution of the levels of acceptance of the illness in relation to the patients' education showed a statistically significant relationship (test probability value $\mathrm{p}=0.0000^{* * *}$ ).

Among those with higher education, the proportion of patients with a high level of acceptance of the illness was 2.5 times higher than among those with primary education (87\% vs. 39\%) (Table 3, Figure 2). 
Table 3. Level of acceptance of illness according to the AIS scale

\begin{tabular}{|c|c|c|c|c|c|}
\hline \multirow{2}{*}{ Level of Acceptance of Illness } & \multicolumn{4}{|c|}{ Education $\left(\mathrm{p}=0.0000^{* * *}\right)$} & \multirow{2}{*}{ Total } \\
\hline & Primary & Vocational & Secondary & Higher & \\
\hline None & $11(28.9 \%)$ & $4(6.6 \%)$ & $4(6.2 \%)$ & $1(6.3 \%)$ & 20 \\
\hline Average & $12(31.6 \%)$ & $30(49.2 \%)$ & $18(27.7 \%)$ & $1(6.3 \%)$ & 61 \\
\hline High & $15(39.5 \%)$ & $27(44.3 \%)$ & $43(66.2 \%)$ & $14(87.5 \%)$ & 99 \\
\hline Total & 38 & 61 & 65 & 16 & 180 \\
\hline
\end{tabular}

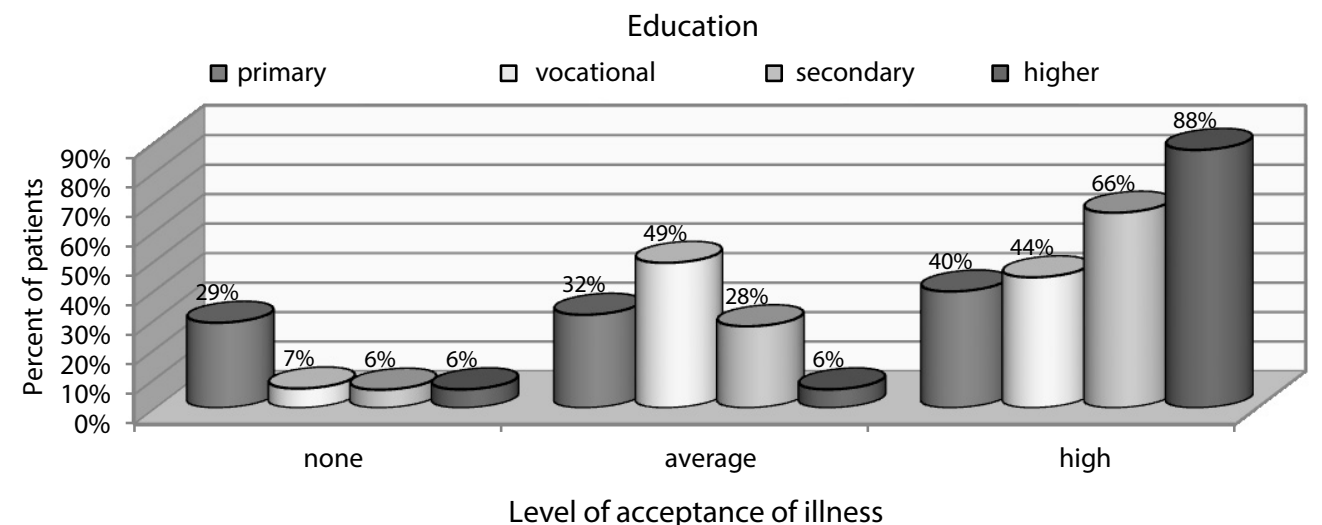

Figure 2. Level of acceptance of illness according to the AIS scale

Using Spearman rank correlation analysis, the relationship between selected factors having a numerical value and the level of acceptance of the illness was examined. Statistically significant correlations were found between age and pain level after surgery and the AIS score (the test probability value p was $0.0000^{* * *}$ for both correlations).

The values of the correlation coefficients were respectively: -0.47 and -0.34 . This means that they were correlations of weak (pain after surgery) or near average (age) strength. The negative value of the correlation coefficient means that the level of acceptance of the disease decreased with age as well as with the level of pain after surgery (Table 4).

Table 4. Correlations between age and severity of pain and the AIS scale score

\begin{tabular}{|c|c|}
\hline Factors & Level of acceptance of illness - AIS \\
\hline Age [years] & $-0.47\left(p=0.0000^{* * *}\right)$ \\
\hline Duration of hospitalization [days] & $-0.13(p=0.0719)$ \\
\hline Pain perceived (before surgery) & $0.08(p=0.2581)$ \\
\hline Pain perceived (after surgery) & $-0.34\left(p=0.0000^{* * *}\right)$ \\
\hline
\end{tabular}

A visualization of the analyses that yielded a statistically significant relationship is presented in the scatter plots below. When the same combinations of both compared variables were present for several individuals, the corresponding marker was increased on the graph. Large scatterplots for a fixed level of the independent factor (age, pain after surgery) reflect the rather low strength of the correlation studied (Figure 3). 

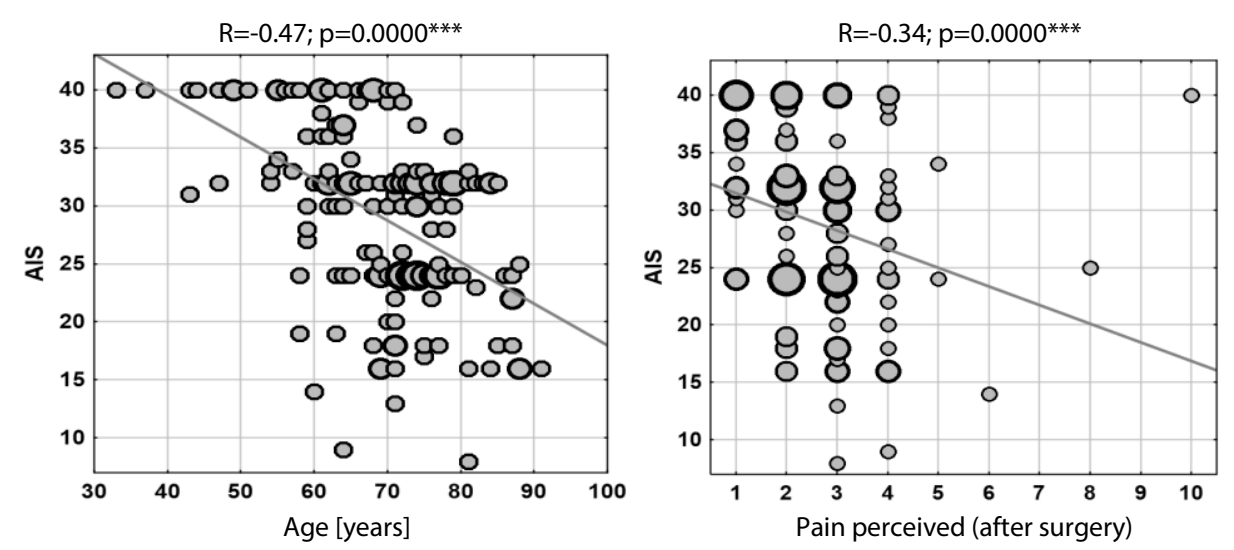

Figure 3. Independent factor level (age, pain after surgery)

The second part examined the influence of selected factors on the subjective assessment of health status according to the SF-36 questionnaire.

Place of residence significantly differentiated most measures of quality of life - the only exceptions were emotional and physical role limitations and pain levels. For the remaining measures, the differences between the groups were statistically significant - the highest quality of life was reported by people from large cities (Table 5).

Table 5. Assessment of quality of life in terms of place of residence

\begin{tabular}{|c|c|c|c|c|c|c|c|}
\hline \multirow{2}{*}{ SF-36 } & \multicolumn{4}{|c|}{ Place of Residence } & \multicolumn{3}{c|}{ City } \\
\cline { 2 - 7 } & \multicolumn{2}{|c|}{ Village } & \multicolumn{2}{c|}{ Town } \\
\cline { 2 - 7 } & $\overline{\boldsymbol{x}}$ & $\boldsymbol{s}$ & $\overline{\boldsymbol{x}}$ & $\boldsymbol{s}$ & $\overline{\boldsymbol{x}}$ & \multicolumn{1}{c|}{ p } \\
\hline Physical functioning & 52.6 & 23.6 & 60.6 & 20.2 & 70.0 & 20.9 & $0.0007^{* * *}$ \\
\hline Role limitations (physical) & 73.7 & 42.8 & 75.9 & 41.4 & 83.3 & 36.2 & 0.5732 \\
\hline Pain & 69.0 & 22.5 & 70.9 & 23.0 & 80.3 & 25.7 & 0.1062 \\
\hline General health & 58.3 & 28.7 & 63.0 & 26.9 & 81.7 & 24.5 & $0.0002^{* * *}$ \\
\hline Role limitations (emotional) & 77.1 & 41.7 & 78.8 & 40.8 & 82.2 & 37.9 & 0.8735 \\
\hline Energy/fatigue & 51.2 & 19.5 & 52.5 & 20.1 & 67.9 & 24.3 & $0.0015^{* *}$ \\
\hline Social functioning & 79.2 & 22.1 & 76.6 & 21.4 & 90.4 & 18.8 & $0.0006^{* * *}$ \\
\hline Emotional well-being & 53.1 & 11.7 & 54.4 & 10.7 & 63.7 & 15.8 & $0.0008^{* * *}$ \\
\hline Physical domain & 59.7 & 23.0 & 65.5 & 18.6 & 75.4 & 22.7 & $0.0007^{* * *}$ \\
\hline Mental domain & 59.6 & 15.7 & 60.6 & 14.1 & 70.7 & 18.1 & $0.0014^{* *}$ \\
\hline Overall quality of life & 59.6 & 18.5 & 63.0 & 14.5 & 73.1 & 19.9 & $0.0003^{* * *}$ \\
\hline
\end{tabular}

Notes: $p$ - test probability value calculated using the Kruskal-Wallis test.

The graphs show the distribution of quality of life in the physical and mental domains in relation to the patients' place of residence (Figure 4). 

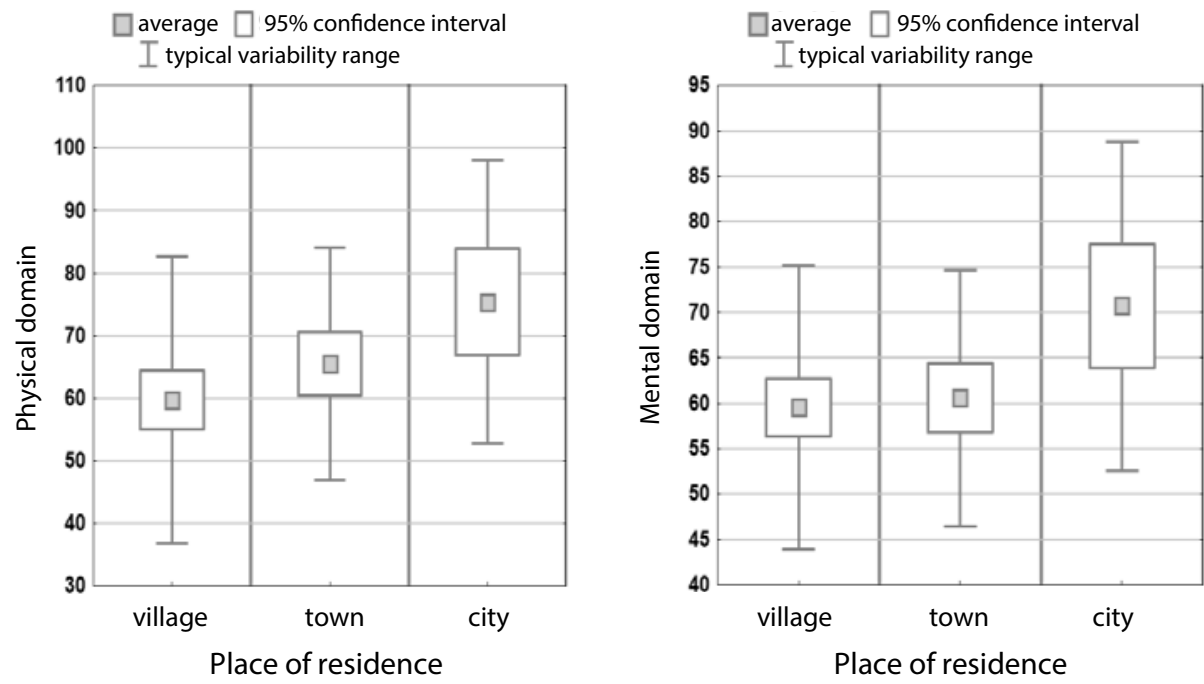

Figure 4. Distribution of physical and mental quality of life in relation to place of residence

Education was also a factor that very clearly differentiated the quality-of-life scores for almost all SF-36 measures. The better the education, the higher the quality-of-life score. The level of quality of life is relatively similar among people with secondary education and vocational education, while the group with primary education is significantly worse, and the best quality of life is found among people with higher education (Figure 5, Table 6).
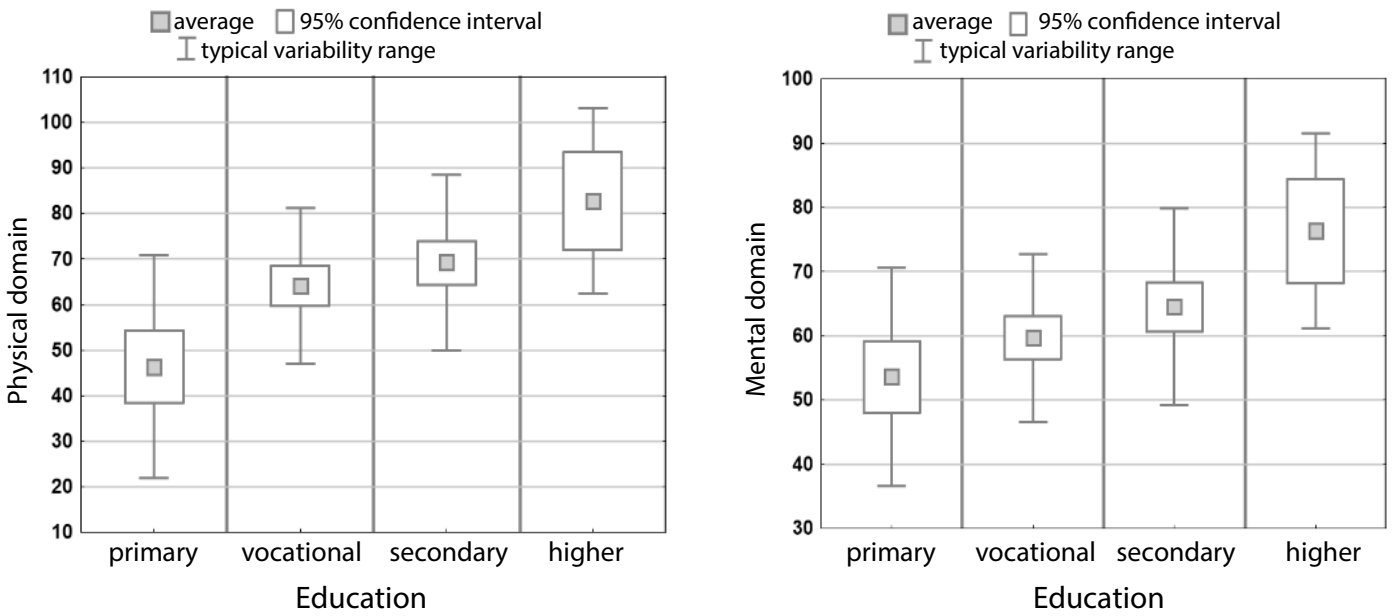

Figure 5. Distribution of physical and mental quality of life in relation to education

Table 6. Evaluation of quality of life in terms of education

\begin{tabular}{|c|c|c|c|c|c|c|c|c|c|}
\hline \multirow{3}{*}{ SF-36 } & \multicolumn{8}{|c|}{ Education } & \multirow{3}{*}{$p$} \\
\hline & \multicolumn{2}{|c|}{ Primary } & \multicolumn{2}{|c|}{ Vocational } & \multicolumn{2}{|c|}{ Secondary } & \multicolumn{2}{|c|}{ Higher } & \\
\hline & $\overline{\boldsymbol{x}}$ & $s$ & $\overline{\boldsymbol{x}}$ & $s$ & $\overline{\boldsymbol{x}}$ & $s$ & $\overline{\boldsymbol{x}}$ & $s$ & \\
\hline Physical functioning & 39.1 & 23.5 & 56.8 & 20.2 & 64.7 & 18.7 & 77.8 & 17.2 & $0.0000^{* * *}$ \\
\hline $\begin{array}{c}\text { Role limitations } \\
\text { (physical) }\end{array}$ & 57.9 & 48.3 & 82.0 & 37.1 & 78.1 & 40.1 & 85.9 & 34.1 & $0.0370^{*}$ \\
\hline Pain & 61.0 & 22.1 & 70.6 & 23.4 & 72.9 & 22.0 & 92.0 & 17.4 & $0.0003^{* * *}$ \\
\hline General health & 45.4 & 28.4 & 59.4 & 25.9 & 70.7 & 25.0 & 92.2 & 19.8 & $0.0000^{* * *}$ \\
\hline
\end{tabular}




\begin{tabular}{|c|c|c|c|c|c|c|c|c|c|}
\hline $\begin{array}{c}\text { Role limitations } \\
\text { (emotional) }\end{array}$ & 65.8 & 48.1 & 82.0 & 37.8 & 80.5 & 39.5 & 85.4 & 34.4 & 0.2541 \\
\hline Energy/fatigue & 45.2 & 20.3 & 49.9 & 16.9 & 57.2 & 20.6 & 78.9 & 18.8 & $0.0000^{* * *}$ \\
\hline Social functioning & 71.7 & 24.1 & 79.3 & 22.3 & 82.7 & 19.6 & 93.0 & 14.4 & $0.0014^{* *}$ \\
\hline Emotional well-being & 49.3 & 11.7 & 52.2 & 9.6 & 58.3 & 12.9 & 68.5 & 13.0 & $0.0000^{* * *}$ \\
\hline Physical domain & 46.4 & 24.5 & 64.2 & 17.1 & 69.3 & 19.4 & 82.8 & 20.2 & $0.0000^{* * *}$ \\
\hline Mental domain & 53.6 & 17.0 & 59.7 & 13.1 & 64.5 & 15.3 & 76.3 & 15.2 & $0.0000^{* * *}$ \\
\hline Overall quality of life & 50.0 & 19.7 & 61.9 & 14.0 & 66.9 & 16.0 & 79.6 & 17.3 & $0.0000^{* * *}$ \\
\hline
\end{tabular}

Notes: $p$ - test probability value calculated using the Kruskal-Wallis test.

The factors that very clearly influenced the patients' quality of life were age and the intensity of pain experienced after surgery. Some correlation coefficients were as high as 0.60 in absolute value and even slightly higher.

The negative values of the correlation coefficients mean that quality of life decreased with age and higher pain intensity. The scatter plots show the correlations between age and perceived pain and quality of life scores in the physical and mental domains (Figure 6).
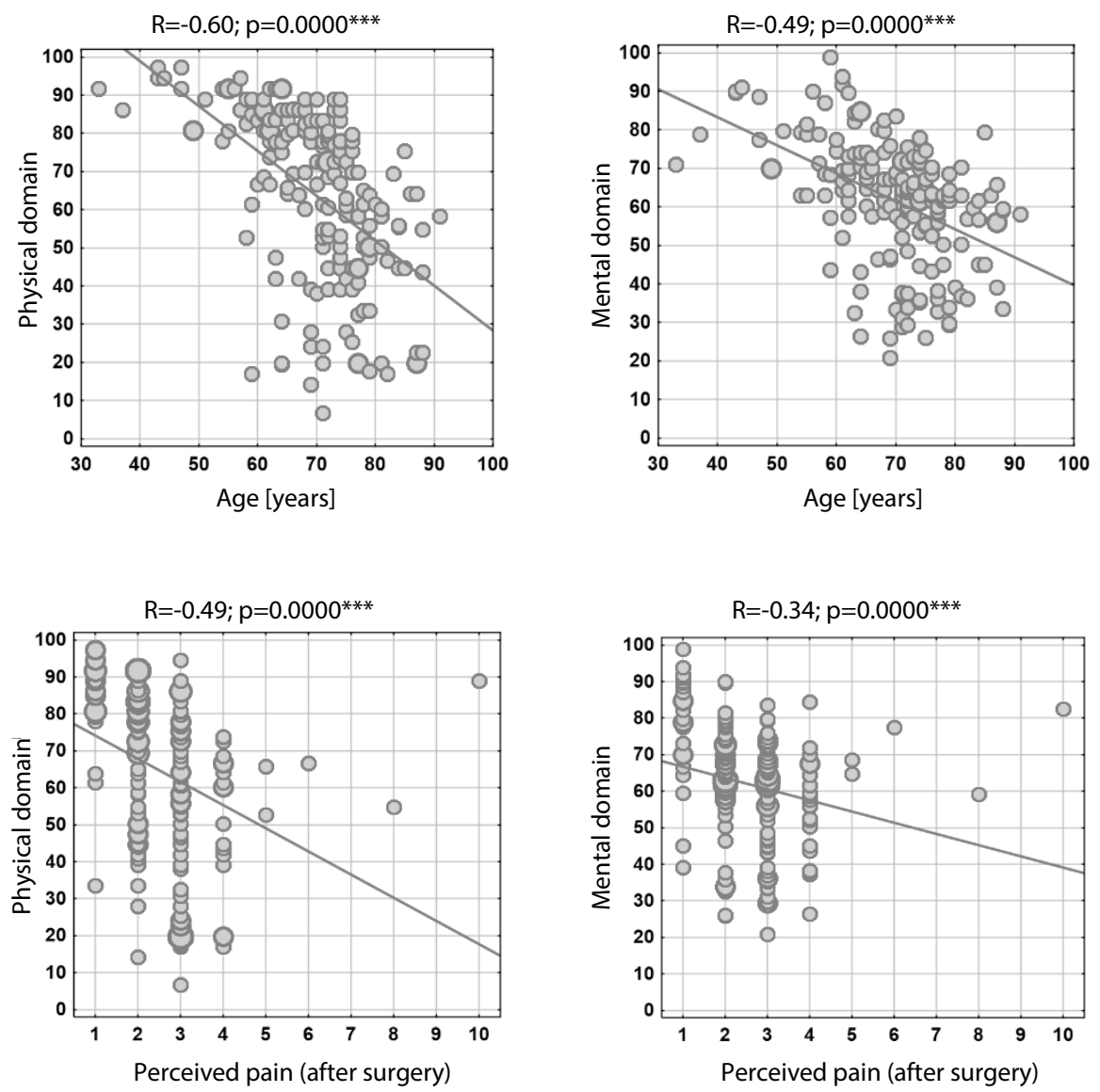

Figure 6. Correlations between age and pain perceived and the quality-of-life scores for physical and mental domains

In the third part, the influence of selected factors on the patients' health status was examined. The WOMAC questionnaire was used as a measure of health status (note that the higher the values of this measure, the worse the self-assessment). 
A very clear difference in the assessment of health status was found between the inhabitants of villages, towns and cities. Inhabitants of cities fared best in this comparison - the average WOMAC was almost 14 points lower than for village inhabitants (Table 7).

Table 7. Evaluation of functional limitations and place of residence according to the WOMAC scale

\begin{tabular}{|c|c|c|c|c|c|c|c|}
\hline \multirow{3}{*}{$\begin{array}{l}\text { Level of Functional } \\
\quad \text { Limitation }\end{array}$} & \multicolumn{6}{|c|}{ Place of Residence } & \multirow{3}{*}{$p$} \\
\hline & \multicolumn{2}{|c|}{ Village } & \multicolumn{2}{|c|}{ Town } & \multicolumn{2}{|c|}{ City } & \\
\hline & $\overline{\bar{x}}$ & $s$ & $\overline{\bar{x}}$ & $s$ & $\overline{\bar{x}}$ & $s$ & \\
\hline WOMAC (pts) & 25.8 & 16.4 & 19.5 & 11.4 & 11.3 & 12.8 & $0.0000^{* * *}$ \\
\hline
\end{tabular}

Notes: $p$ - test probability value calculated using the Kruskal-Wallis test.

Education also significantly differentiated the assessment of the level of mobility. Participants with primary education had, on average, about 30 points higher levels of disability in their self-assessment than those with higher education (Table 8, Figure 7).

Table 8. Evaluation of functional limitation and education according to the WOMAC scale

\begin{tabular}{|c|c|c|c|c|c|c|c|c|c|}
\hline \multirow{3}{*}{$\begin{array}{l}\text { Level of Functional } \\
\text { Limitation }\end{array}$} & \multicolumn{8}{|c|}{ Education } & \multirow{3}{*}{$p$} \\
\hline & \multicolumn{2}{|c|}{ Primary } & \multicolumn{2}{|c|}{ Vocational } & \multicolumn{2}{|c|}{ Secondary } & \multicolumn{2}{|c|}{ Higher } & \\
\hline & $\overline{\boldsymbol{x}}$ & $s$ & $\overline{\boldsymbol{x}}$ & $s$ & $\overline{\boldsymbol{x}}$ & $s$ & $\overline{\boldsymbol{x}}$ & $s$ & \\
\hline WOMAC (pts) & 36.7 & 15.0 & 23.6 & 12.2 & 15.1 & 10.6 & 4.5 & 8.3 & $0.0000^{* * *}$ \\
\hline
\end{tabular}

Notes: $p$ - test probability value calculated using the Kruskal-Wallis test.
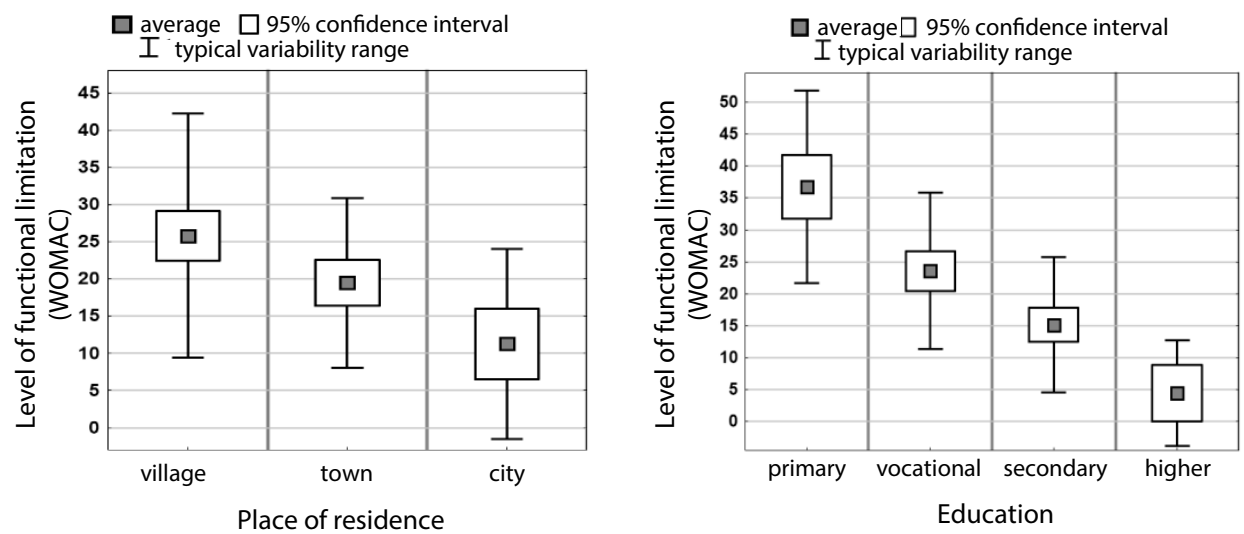

Figure 7. Evaluation of functional limitation and education according to the WOMAC scale

All factors, except for the level of pain before surgery, had a statistically significant effect on the degree of functional limitation according to the WOMAC scale. The lack of influence of the patient's condition before surgery is understandable because at the time of filling in the questionnaire, this "memory" was no longer clear, and the current level of pain was the determining factor for functional limitation. The factor most strongly affecting the level of functional limitation was age $(\mathrm{R}=0.63)$. This is probably due to two overlapping effects the natural deterioration of functional capacity with age, which also occurs in healthy people, and the greater severity of hip disease in older patients (Table 9, Figure 8).

Table 9. Evaluation of physical limitation between age, duration of hospitalization and pain experienced before and after surgery

\begin{tabular}{|c|c|}
\hline Factors & Level of Functional Limitation (WOMAC) \\
\hline Age [years] & $\mathbf{0 . 6 3}(p=\mathbf{0 . 0 0 0 0 * * *})$ \\
\hline Duration of hospitalization [days] & $\mathbf{0 . 3 2}\left(p=\mathbf{0 . 0 0 0 0 ^ { * * * } )}\right.$ \\
\hline Pain perceived (before surgery) & $-0.01(p=0.9398)$ \\
\hline Pain perceived (after surgery) & $\mathbf{0 . 3 7}\left(\boldsymbol{p}=\mathbf{0 . 0 0 0 0 ^ { * * * } )}\right.$ \\
\hline
\end{tabular}


a)

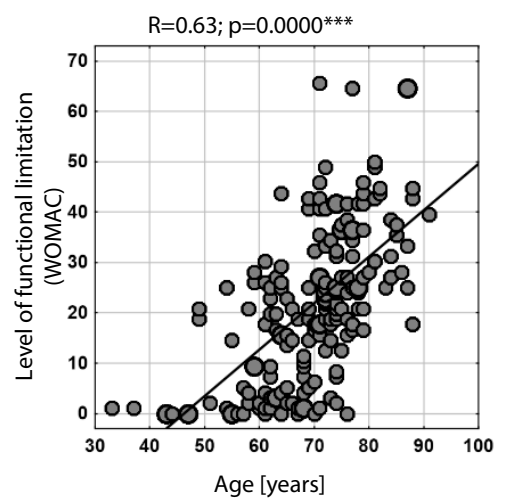

b)

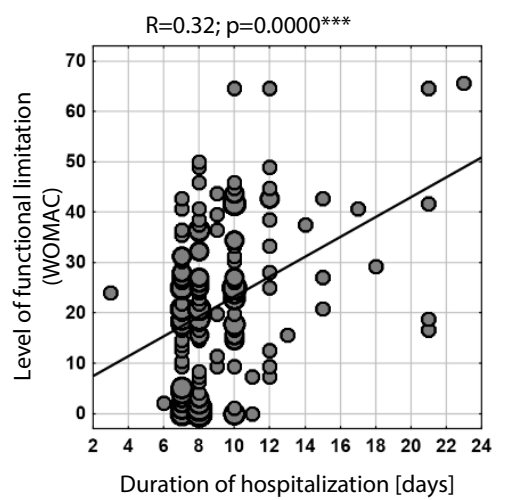

c)

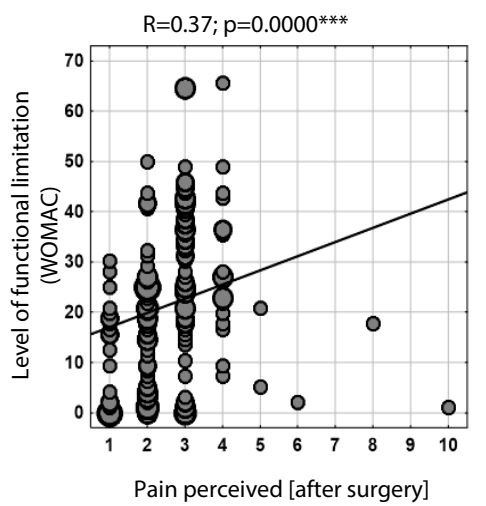

Figure 8. Evaluation of the level of physical limitation between age, duration of hospitalization and pain perceived before and after surgery

The next stage was to examine the influence of selected factors on the opinion of the level of pain - scores calculated using the BPCQ questionnaire were used here. These results seem to be important from a practical point of view as beliefs about the sources of pain undoubtedly influence the patient's participation in the rehabilitation process. People who believe that the level of pain is primarily influenced by chance will be less "conscientious" patients and these patients should have more psychological support. It is better if the patient believes that pain levels are influenced by doctors or internal factors, i.e. the patient's lifestyle.

The place of residence did not statistically significantly differentiate the opinions of the patients surveyed on factors affecting pain levels. Results of the analysis are presented in Table 10.

Table 10. Evaluation of the level of pain control and place of residence according to the BPCQ scale

\begin{tabular}{|c|c|c|c|c|c|c|c|}
\hline \multirow{3}{*}{$\begin{array}{l}\text { Pain control methods } \\
\text { (BPCQ) }\end{array}$} & \multicolumn{6}{|c|}{ Place of Residence } & \multirow{3}{*}{$p$} \\
\hline & \multicolumn{2}{|c|}{ Village } & \multicolumn{2}{|c|}{ Town } & \multicolumn{2}{|c|}{ City } & \\
\hline & $\overline{\bar{x}}$ & $s$ & $\overline{\bar{x}}$ & $s$ & $\overline{\bar{x}}$ & $s$ & \\
\hline Internal & 57.5 & 18.0 & 55.6 & 17.1 & 59.3 & 15.2 & 0.8316 \\
\hline Doctors' influence & 68.6 & 20.5 & 69.6 & 14.4 & 63.6 & 18.1 & 0.1357 \\
\hline Pure chance & 69.1 & 15.7 & 65.9 & 17.1 & 61.4 & 17.3 & 0.0819 \\
\hline
\end{tabular}

Notes: $p$ - test probability value calculated using the Kruskal-Wallis test.

Better educated people attached less importance to the impact of chance events on pain levels. In the group of people with primary education, the chance factor was perceived as the most important (mean score of 75.1 points), while in the group of people with higher education, it was regarded as much less important (mean score of 59.7 points) (Table 11, Figure 9).

Table 11. Assessment of pain control and education according to the BPCQ

\begin{tabular}{|c|c|c|c|c|c|c|c|c|c|}
\hline \multirow{3}{*}{$\begin{array}{l}\text { Pain control } \\
\text { methods (BPCQ) }\end{array}$} & \multicolumn{8}{|c|}{ Education } & \multirow{3}{*}{$p$} \\
\hline & \multicolumn{2}{|c|}{ Primary } & \multicolumn{2}{|c|}{ Vocational } & \multicolumn{2}{|c|}{ Secondary } & \multicolumn{2}{|c|}{ Higher } & \\
\hline & $\overline{\boldsymbol{x}}$ & $s$ & $\overline{\boldsymbol{x}}$ & $s$ & $\overline{\boldsymbol{x}}$ & $s$ & $\overline{\boldsymbol{x}}$ & $s$ & \\
\hline Internal & 58.7 & 16.9 & 59.1 & 16.3 & 54.5 & 18.5 & 57.8 & 16.8 & 0.5650 \\
\hline Doctors' influence & 71.6 & 19.6 & 69.3 & 16.4 & 65.0 & 19.5 & 66.6 & 19.5 & 0.2259 \\
\hline Pure chance & 75.1 & 13.1 & 68.3 & 15.5 & 62.6 & 17.2 & 59.7 & 17.2 & $0.0005^{* * *}$ \\
\hline
\end{tabular}

Notes: $p$ - test probability value calculated using the Kruskal-Wallis test. 


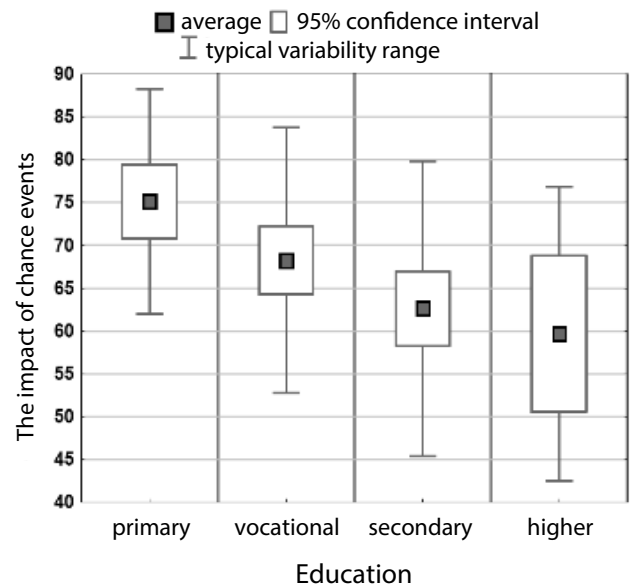

Figure 9. Assessment of pain control and education according to the BPCQ

From the results of the subsequent analysis, it can be concluded that only age had a statistically significant effect on perceptions regarding the factors influencing the level of pain. Interestingly, the weight ascribed to all factors increased with age, although the strongest correlation $(\mathrm{R}=0.45)$ concerned the influence of chance. Thus it can be concluded that among the elderly, the relative "belief" in the inability to overcome pain, in fate or chance was higher than among younger patients (Table 12, Figure 10).

Table 12. Assessment of pain control and age according to BPCQ

\begin{tabular}{|c|c|c|c|}
\hline \multirow{2}{*}{ Factors } & \multicolumn{2}{|c|}{ Pain control methods (BPCQ) } \\
\cline { 2 - 4 } & Internal & Doctors' influence & Chance events \\
\hline Age [years] & $\begin{array}{c}\mathbf{0 . 3 4} \\
(\boldsymbol{p}=\mathbf{0 . 0 0 0 0 * * )}\end{array}$ & $\begin{array}{c}\mathbf{0 . 2 9} \\
\left.(\boldsymbol{p}=\mathbf{0 . 0 0 0 1})^{* *}\right)\end{array}$ & $\begin{array}{c}\mathbf{0 . 4 5} \\
(\boldsymbol{p}=\mathbf{0 . 0 0 0 0}\end{array}$ \\
\hline Duration of hospitalization [days] & $\begin{array}{c}0.06 \\
(p=0.4460)\end{array}$ & $\begin{array}{c}0.09 \\
(p=0.10\end{array}$ \\
\hline Pain perceived (before surgery) & $\begin{array}{c}-0.01 \\
(p=0.9356)\end{array}$ & $\begin{array}{c}0.165) \\
(p=0.1093)\end{array}$ & $\begin{array}{c}-0.02 \\
(p=0.7720)\end{array}$ \\
\hline Pain perceived (after surgery) & $\begin{array}{c}0.09 \\
(p=0.2326)\end{array}$ & $\begin{array}{c}0.09 \\
(p=0.2314)\end{array}$ & $\begin{array}{c}\mathbf{0 . 1 7} \\
(\boldsymbol{p}=\mathbf{0 . 0 2 7 3})\end{array}$ \\
\hline
\end{tabular}

Notes: $p$ - test probability value calculated using the Kruskal-Wallis test.

a)

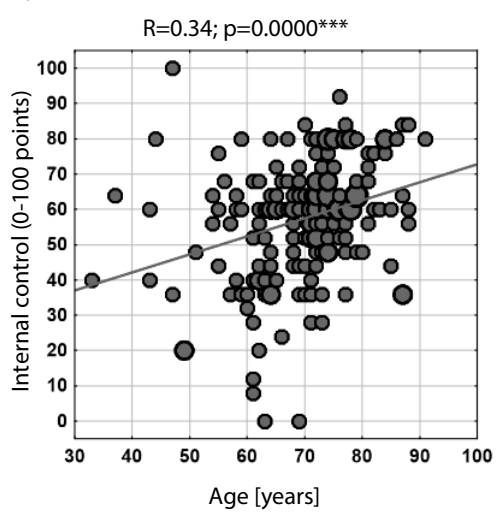

b)

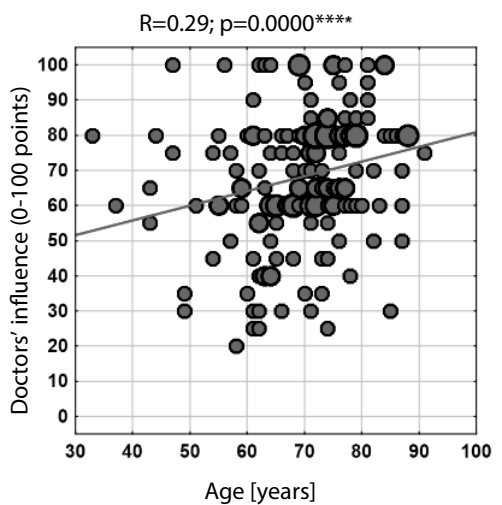

c)

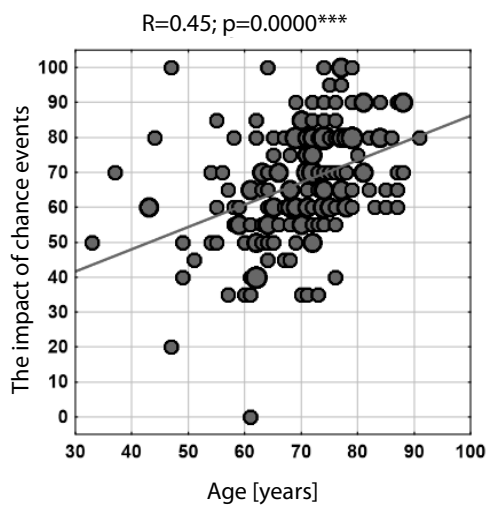

Figure 10. Assessment of pain control and age according to BPCQ

The influence of selected factors on the assessment of pain management and pain reduction skills was also analyzed. For this purpose, answers to questions included in the CSQ questionnaire were evaluated.

Place of residence did not differentiate self-assessment of pain control or pain reduction. Education also had no effect on these values (Table 13). 
Table 13. CSQ scale in relation to place of residence and education

\begin{tabular}{|c|c|c|c|c|c|c|c|c|c|}
\hline \multirow{3}{*}{ CSQ questionnaire } & \multicolumn{8}{|c|}{ Place of Residence } & \multirow{3}{*}{$p$} \\
\hline & \multicolumn{3}{|c|}{ Village } & \multicolumn{2}{|c|}{ Town } & \multicolumn{3}{|c|}{ City } & \\
\hline & $\overline{\boldsymbol{x}}$ & \multicolumn{2}{|c|}{$s$} & $\overline{\bar{x}}$ & $s$ & \multicolumn{2}{|c|}{$\overline{\boldsymbol{x}}$} & $s$ & \\
\hline Control over pain & 3.67 & \multicolumn{2}{|c|}{0.95} & 3.72 & 1.0 & \multicolumn{2}{|c|}{4.00} & 1.02 & 0.3199 \\
\hline Reduction in pain & 3.52 & \multicolumn{2}{|c|}{0.97} & 3.76 & 1.0 & \multicolumn{2}{|c|}{3.96} & 0.96 & 0.1693 \\
\hline \multirow{3}{*}{ CSQ questionnaire } & \multicolumn{8}{|c|}{ Education } & \multirow{3}{*}{$p$} \\
\hline & \multicolumn{2}{|c|}{ Primary } & \multicolumn{2}{|c|}{ Vocational } & \multicolumn{2}{|c|}{ Secondary } & \multicolumn{2}{|c|}{ Higher } & \\
\hline & $\overline{\boldsymbol{x}}$ & $s$ & $\overline{\boldsymbol{x}}$ & $s$ & $\overline{\boldsymbol{x}}$ & $s$ & $\overline{\boldsymbol{x}}$ & $s$ & \\
\hline Control over pain & 3.89 & 0.86 & 3.62 & 1.00 & 3.74 & 1.07 & 3.75 & 0.86 & 0.5271 \\
\hline Reduction in pain & 3.66 & 0.91 & 3.57 & 1.10 & 3.73 & 1.01 & 3.75 & 0.86 & 0.9279 \\
\hline
\end{tabular}

Notes: $p$ - test probability value calculated using the Kruskal-Wallis test.

Patients hospitalized for longer periods of time perceived the possibility of pain control and pain reduction as higher. On the other hand, age did not influence the assessment of these issues at all, whereas the influence of perceived pain was on the verge of statistical significance, yet the strength of this influence turned out to be so small ( $R$ does not exceed 0.20 ) that these results can be ignored in practical interpretations (Table 14).

Table 14. CSQ scale in relation to age, duration of hospitalization and pain

\begin{tabular}{|c|c|c|}
\hline \multirow{2}{*}{ Factors } & \multicolumn{2}{|c|}{ CSQ questionnaire } \\
\cline { 2 - 3 } & Control over pain & Reduction in pain \\
\hline Age [years] & $-0.05(p=0.4991)$ & $-0.06(p=0.4416)$ \\
\hline Duration of hospitalization [days] & $\mathbf{0 . 2 9}\left(\boldsymbol{p}=\mathbf{0 . 0 0 0 1}\right.$ ***) $\left.^{* *}\right)$ & $\mathbf{0 . 2 3}\left(\boldsymbol{p}=\mathbf{0 . 0 0 2 5 ^ { * * } )}\right.$ \\
\hline Pain perceived (before surgery) & $-0.11(p=0.1367)$ & $\mathbf{- 0 . 1 7}\left(\boldsymbol{p}=\mathbf{0 . 0 2 0 6 ^ { * } )}\right.$ \\
\hline Pain perceived (after surgery) & $\mathbf{- 0 . 1 3}(\boldsymbol{p}=\mathbf{0 . 0 7 5 2 )}$ & $\mathbf{- 0 . 1 3}(\boldsymbol{p}=\mathbf{0 . 0 8 2 0})$ \\
\hline
\end{tabular}

\section{Discussion}

One of the most distressing symptoms of osteoarthrosis is increasing pain, which leads to a gradual increase in the consumption of painkillers and often their overuse [15]. The same pain, or rather the reduction of its intensity, serves as a reference for the assessment of the effectiveness of the performed endoprosthetic surgery. Pain is not only a medical symptom but has a negative effect on the emotional, cognitive and behavioral domains. It creates a distorted perception of one's life situation, contributes to depression, lowers mood and quality of life, causes withdrawal from active life, and worsens interpersonal relationships with the people closest to the patient. It is estimated that every 13th person takes painkillers on a daily basis due to severe hip pain [16,17]. Chronic pain is a predominant problem in patients with hip osteoarthritis and can take particular forms as it affects not only the physical aspects of a patient's functioning but also the social and psychological [18,19]. The functioning of patients experiencing pain clearly impairs their quality of life and limits their independence. Initially, there is usually post-exertional pain, manifested by symptoms around the hip joint. Further tissue deterioration promotes the development of rest pain, resulting in reduced physical activity and locomotion. In patients with advanced disease, nocturnal pain of intra-articular origin occurs, and this is most often an indication for endoprosthesis of the joint $[18,19]$. Literature analysis of pain severity scales shows that after total hip replacement surgery, the pain experienced is significantly reduced and no longer a major obstacle in daily activities, as compared to before surgery. This was proven, for example, by Kieszkowska-Grudny [20] in a study group of patients. She found that pain after surgery was reduced in as many as $75 \%$ of the patients who underwent statistical examination. The therapeutic effect obtained was a direct reduction of painfulness, favoring less involvement of thoughts, positively changing the patients' behavior and becoming manageable, which resulted in increased control over the disease, unpleasant symptoms and their lives. When pain is reduced, there is motivation to take control of one's health and life [20]. Our research also confirms the positive impact of total hip replacement surgery and the improvement in patients' quality of life. The research found that in self- 
reported pain after surgery, pain levels decreased significantly in $96 \%$ of subjects after surgery (on average by more than 6 points, from 8.8 points to 2.6 points).

In order to assess the level of adaptation to the illness and the intensity of negative emotions causing the feeling of psychological discomfort, a survey was conducted using the Acceptance of Illness Scale (AIS) [21]. In the literature, it is noted that individuals may react differently to the facts of the disease - either accepting this state or not reconciling with the situation [22,23]. It is also emphasized that people who are able to accept their illness are usually more willing to undertake the challenge of recovery and experience fewer negative emotions and feelings [22,23].

Sochacka [24] analyzed the level of acceptance of a chronic illness on the example of patients with osteoarthritis and examined the influence of factors shaping a specific level of acceptance of the illness. Patients participating in the study overwhelmingly described the level of acceptance of the illness as medium (61.0\%). Low level pertained to 37\% of people, and high level to 2\% [24]. Kurowska and Rumińska [25] studied 98 patients after hip alloplasty from the Trauma and Orthopaedic Department of the Regional Polyclinic Hospital in Toruń located at św. Józefa St. The mean level of acceptance of the illness (AIS) was 23.7 points, which indicates an average adaptation to the illness. Definite acceptance of the illness was displayed by only $31.6 \%$ of patients (scored above 30 points). The authors noted no statistically significant gender difference between the groups in terms of acceptance of the illness [25].

In our study, more than half of the studied patients (55.2\%) obtained a high score for acceptance of the illness. Based on their study, Niedzielski et al. [26] report that the level of acceptance of the illness is not clearly determined by the type of illness that was diagnosed in the patient. An important variable is whether or not it is a chronic condition. In a study by Sochacka [24], women demonstrated a significantly higher level of acceptance of illness, defining the level as moderate or high in $70.6 \%$, while in men, such a level of acceptance was observed in only $55.1 \%$ of respondents.

It was also found that among persons with higher education, the number of patients with a high level of acceptance of the illness was 2.5 times higher than among persons with primary education. Analysis of the level of acceptance of the illness according to the education of respondents in Sochacka's study [24] showed that respondents with higher and secondary education felt a higher level of acceptance of the illness than those with primary and vocational education. In a study by Gajewski et al. [27], it was also demonstrated that the higher the level of education, the higher the percentage of satisfied respondents who reported a higher quality of life [27]. Our study confirms the fact that patients with a higher level of education showed a much higher level of acceptance of the illness (35.6\%). Among those with higher education, the proportion of patients with a high level of acceptance of the illness was 2.5 times higher than among those with primary education. This was not confirmed in the study by Moczydłowska et al. [28], which showed that in both groups of patients from surgical and treatment wards, the results were very similar and the greatest proportion of respondents, irrespective of their education, showed an intermediate level of acceptance of the illness, falling within the range of 19-29 points. In surgical wards, the highest value was obtained by patients with secondary education (82.6\%) and in treatment wards by patients with vocational education (73.6\%), but these differences were not statistically significant [28]. It is believed that patients living in a city showed a slightly higher level of acceptance of the illness of osteoarthritis compared to village residents. Such results were obtained, e.g. in studies by the teams of Sierakowska et al. [29] and Gajewski et al. [27], where the vast majority of respondents living in the city achieved a higher level of quality and satisfaction with life than those living in villages. In a study by Moczydłowska et al. [28], both in surgical and treatment wards, the highest score of intermediate acceptance of the illness (in the range of 19-29 points on the AIS scale) was obtained in groups of urban residents (79.6\% vs. $71.2 \%$, respectively). The above findings are also confirmed by the analysis of our results, which indicate that the place of residence quite clearly differentiated the level of acceptance of the illness - a particularly high difference was observed between patients from cities and residents of villages, which confirms the studies conducted by other authors.

Konieczny et al. [30] highlighted the introduction of modern standards of nursing care and rehabilitation of patients after hip replacement surgery. Careful attention is paid to the fact that rehabilitation itself is not only rehabilitation of the operated limb but also learning about self-care and living in new circumstances. According to the authors mentioned above, increasing the knowledge and sensitizing nursing staff to the problems of rehabilitation and self-care, as well as preparing the patient for life with an endoprosthesis, has a major impact on their quality of life, as well as on the assessment of the quality of medical care provided [30]. The study by Kokoszka et al. [31] demonstrates that a significant factor affecting the functional status after total hip replacement is the level of patient education concerning the hip joint operated on as well as limitations in everyday postoperative life and professional activities. 


\section{Conclusions}

Age, place of residence and education did not differentiate the self-assessment of pain control and ability to reduce the perception of pain, but a greater ability to control pain and ability to reduce pain was perceived by persons with longer hospitalization times. The highest quality of life was found in patients from large cities; the better the education, the higher the quality-of-life score; quality of life decreased with age and increased pain intensity. All components of the quality-of-life scale, calculated using the SF-36 questionnaire, were statistically significantly correlated with the level of acceptance of the illness - the better the quality of life, the higher the level of acceptance of the illness and vice versa.

Belief about the sources of pain control was correlated with the level of acceptance of illness, with very weak correlations for ratings of the importance of internal control and the influence of doctors; the greater the belief in the inevitability of experiencing pain in the face of the dominant importance of chance events, the lower the level of acceptance of illness.

\section{Postulates}

The recovery of the patient after hip replacement obliges the nurse not only to perform activities related to care but also to recognize bio-psycho-social needs, to strive to implement professional rehabilitation as early as possible and to prepare the patient for self-treatment and self-care.

An important part of the preoperative and postoperative stages should be patient education. The patient must be provided with basic information about the procedure and the safety measures to be taken afterwards, at home. The patient must be instructed in all possible prophylactic measures to minimize the risk of hip prosthesis dislocation, reduced material wear and loosening. The patient should also be made aware of his/her limitations and the desirability/purpose of gradually introducing physical activity.

These measures should become the standard of care for patients after hip replacement.

\section{References:}

1. Nowakowski A, Mazurek T. [Orthopedics and traumatology. Textbook for medicine students]. Poznań: Wydawnictwo Naukowe Exemplum; 2017. p. 5, 608 (in Polish).

2. Culliford DJ, Maskell J, Kiran A. The lifetime risk of total hip and knee arthroplasty: results from the UK general practice research database. Osteoarthritis Cartilage. 2012; 20(6): 519-524. https://doi.org/10.1016/j. joca.2012.02.636

3. Murphy LB, Helmick CG, Schwartz TA. One in four people may develop symptomatic hip osteoarthritis in his or her lifetime. Osteoarthritis Cartilage. 2010; 18(1): 1372-1379. https://doi.org/10.1016/j.joca.2010.08.005

4. Zembaty A. [Kinesiotherapy]. Kraków: Kasper; 2002 (in Polish).

5. Ridan Ogrodzka K, Kliś A. [Rehabilitation process after after hip joint alloplasty]. Praktyczna Fizjoterapia i Rehabilitacja. 2013; 7-22 T, (in Polish).

6. Wojciechowski P, Kusz D, Iwaniak A, Cieliński Ł. [Results analysis of the total knee joint alloplasty conducted at the Institute and Clinic of Orthopedics and Musculoskeletal Traumatology of Silesian Medical Academy in Katowice]. Chirurgia Kolana Artroskopia Traumatologia. Sport. 2006; 3: 19-26 (in Polish).

7. Żuk T, Dziak A, Gusta A. [Basics of Orthopedics]. Warszawa: Wydawnictwo Lekarskie PZWL; 1993 (in Polish).

8. Buczek N, Dzierżanowski M, Hagner W, Włodarczyk M. [Patient's age as the factor influencing early hospital recovery after total alloplasty of the hip joint]. Kwartalnik Ortopedyczny. 2008; 1: 80-89 (in Polish).

9. Schwarz EM, Looney RJ, O'Keefe RJ. Anti-TNF-alpha therapy as a clinical intervention for periprosthetic osteolysis. Arthritis Research. 2000; 2(3): 165-168. https://doi.org/10.1186/ar81

10. Mamlin LA, Melfi CA, Parchman ML, Gutierrez B, Allen DI, Katz BP, et al. Management of osteoarthritis of the knee by primary care physicians. The Archives of Family Medicine. 1998; 7(6): 563-567. https://doi. org/10.1001/archfami.7.6.563

11. Polish National Health Fund. [Joint alloplasty performance in 2016] [Internet]. Warszawa: Polish National Health Fund (NFZ) [cited 2018 Oct 3]. Available from: http://www.nfz.gov.pl/o-nfz/publikacje (in Polish).

12. Ossowska M, Bednarczyk-Rosolak B, Sterkowicz T. [Early results of therapeutic rehabilitation among patients after hip joint alloplasty]. Współczesne Pielęgniarstwo i Ochrona Zdrowia. 2016; 5(3): 75-79 (in Polish).

13. Różańska M, Żołyński K, Pawlik Z, Błaszczyk-Suszyńska J, Żołyński A, Cieślik P, et al. [The assessment of the physical capacity of the hip joint after cementless alloplasty]. Kwartalnik Ortopedyczny. 2002; 1(1): 39-50 (in Polish). 
14. Pozowski A. [I've got an artificial hip joint]. Warszawa: PZWL; 2002 (in Polish).

15. Dutka J, Dutka $Ł$, Janiszewska M, Hajduk G. [The analysis of costs and medical and social aspects of operative and non-operative hip osteoarthritis treatment]. Ortopedia Traumatologia Rehabilitacja. 2008; 6: 537-544 (in Polish).

16. Nalazek A, Kamińska E, Kaźmierczak U, Trela E. [Treatment, diagnosis and prevention of hip replacement for osteoarthritis]. Journal of Health Sciences. 2014; 4(1): 333-338 (in Polish).

17. Zimmerman-Górska I, Białkowska-Puszczewicz G, Puszczewicz M. [Joint fluid analysis. 2nd edition]. Poznań: UM Poznań; 1997 (in Polish).

18. Badura-Brzoza K, Zając P, Matysiakiewicz J, Piegza M, Rycerski W, Hese RT, et al. [The association of quality of life with mental status and sociodemographic data in patients after total hip replacement]. Psychiatria Polska. 2008; 42(2): 261-269 (in Polish).

19. Biegański P, Polewska E. [The hip joint osteoarthritis - patient and functional problems]. Journal of Health Sciences. 2015; 5(8): 47-54 (in Polish).

20. Kieszkowska-Grudny A, Maleszewska J, Siwy-Hudowska A, Nawrocki S. [Assessment of health related quality of life and coping strategies in patients undergoing the hip replacement surgery]. Gerontoogia Polska. 2014; 2: 62-69 (in Polish).

21. Juczyński Z. [Assessment tools in health promotion and psychology]. Warszawa: Pracownia Testów Psychologicznych Polskiego Towarzystwa Psychologicznego; 2009 (in Polish).

22. Moczydłowska A, Krajewska-Kułak E, Kózka M, Bielski K. [Degree of patients' life satisfaction when hospitalised in treatment and behavioural wards]. Pielęgniarstwo Chirurgiczne i Angiologiczne. 2014; 1: 24-34 (in Polish).

23. Kossakowska M. [Strategies of coping with chronic illness in patients with multiple sclerosis]. Post. Psych. Neurol. 2008; 17: 15-21 (in Polish).

24. Sochacka A. [Assessment of the acceptability of the chronic disease by patients with osteoarthritis]. Innowacje w Pielęgniarstwie i Naukach o Zdrowiu. 2016; 3(1) (in Polish). https://doi.org/10.21784/IwP.2016.013

25. Kurowska K, Rumińska B. [Disease acceptance and coping with stress in patients after hip jointendoprosthesis implantation]. Pielęg. Chir. Angiol. 2011; 4: 203-210 (in Polish).

26. Niedzielski A, Humeniuk E, Błaziak P, Fedoruk D. [The acceptance level in chosen chronic diseases]. Wiad. Lek. 2007; 60(5-60): 224-227 (in Polish).

27. Gajewski T, Woźnica I, Młynarska M, Ćwikła S, Strzemecka J, Bojar I. [Selected aspects of quality of life of patients with degenerative changes in the spine and joints]. Medycyna Ogólna i Nauki o Zdrowiu. 2013; 19(3): 362-369 (in Polish).

28. Moczydłowska A, Krajewska-Kułak E, Kózka M, Bielski K. [The level of life satisfaction of patients hospitalized at the surgical and non-invasive treatment wards]. Pielęgniarstwo Chirurgiczne i Angiologiczne. 2014; 1: 2434 (in Polish).

29. Sierakowska M, Sierakowski S, Wróblewska M, Krajewska-Kułak E. [Health problems of patients with joints osteoarthritis and their influence on the quality of life dependent on health status]. Reumatologia. 2010; 48(6): 372-379 (in Polish).

30. Konieczny P, Piechowicz J, Kotela I. [Nursing care standard in patients after hip joint alloplasty]. Przegląd Lekarski. 2010; 67(5): 389-393 (in Polish).

31. Kokoszka P, Staszczuk P, Redman M, Piślewski Z, Pietrzak K. [Assessment of remote results of hip joint alloplasty with a Zweymuller type cementless prosthesis]. Chirurgia Narządu Ruchu. Ortp. Pol. 2008; 73: 22 (in Polish). 